\title{
UNREST AND REGIME CHANGE IN THE ARAB WORLD: MYTHS AND REALITY
}

\author{
James Petras
}

\section{INTRODUCTION}

he events from mid-February to early March 2011 includ-
ing among others an outbreak of protest and unrest in Tu-
nisia, resulting in the downfall of the government; a political revolution of sorts in Egypt and the overthrow of the tyrant Mubarak, and a serious challenge to the rule of Colonel Gaddafi in Libya, comprised a short period in which, to quote Adam Hanieh (2011), «the lessons of many decades can be telescoped into a few brief moments and seemingly minor occurrences can take on immense significance». Developments in Egypt were particularly significant. The entry of millions of Egyptians onto the political stage graphically illuminated the processes that underlie the politics of the Middle East. Among other things, «it has laid bare the long-standing complicity of the US and other world powers with the worst possible regimes, revealed the empty and hypocritical rhetoric of US President Barack Obama and other leaders, exposed the craven capitulation of all the Arab regimes, and demonstrated the real alliances between these regimes, Israel and the USA». «These are», as Hanieh notes, «political lessons that will long be remembered» (ibid).

The uprisings have also shown «the remarkable fragility of the nepotistic regimes across the Arab world. These regimes depended upon their networks of secret police (mukhabarat) and thugs (baltajiya), and inculcated a seemingly unassailable pessimism about the possibility of change that was reflected in the biting sarcasm of Arab political humour». But, as Hanieh notes, «these mechanisms 
of control simply evaporated as people shed their fear». The Arabic word intifada, he further notes «conveys this sense of shaking off, and the sight of millions of people losing their fear and gaining a sense of the possible will long remain one of the most enduring memories of this revolutionary moment». The historic significance of this process should not be lost: there has quite literally never been a moment of such potential in the Arab world.

The purpose of this chapter is not to recount the story of these uprisings or to predict the possible future scenarios of the revolutionary process in the Arab world. Rather, it aims to draw out some of the broader implications for the Middle East as a whole, and to argue that these struggles are best understood through the lens of class struggle. The recent uprisings in the Arab world of Middle-East and North Africa show decisively that class remains the key dynamic to understanding any social transformation and, simultaneously, that the ways in which «class struggle» is expressed will take a variety of forms that disrupts any reductionist economistic or political readings of events.

\section{I \\ ROOTS OF THE ARAB REVOLTS AND PREMATURE CELEBRATIONS}

Most accounts of the Arab revolts from Egypt, Tunisia, Libya, Morocco, Yemen, Jordan, Bahrain, Iraq and elsewhere have focused on the most immediate causes: political dictatorships, unemployment, repression and the wounding and killing of protestors. They have given most attention to the «middle class», young, educated activists, their communication via the internet, (Los Angeles Times, Feb. 16, 2011) and, in the case of Israel and its Zionists conspiracy theorists, «the hidden hand» of Islamic extremists (Daily Alert, February 25, 2011).

What is lacking is any attempt to provide a framework for the revolt that takes account of the large-scale, long —and medium - term socioeconomic structures as well as the immediate «detonators» of political action. The scope and depth of the popular uprisings, as well 
as the diverse political and social forces which have entered into the conflicts, preclude any explanations that look at one dimension of the struggles.

The best approach involves a «funnel framework» in which, at the wide end (the long-term, large-scale structures), stands the nature of the economic, class and political system; the middle-term is defined by the dynamic cumulative effects of these structures on changes in political, social and economic relations; the short-term causes, which precipitate the socio-political-psychological responses, or social consciousness leading to political action.

\section{The nature of the Arab economies}

With the exception of Jordan, most of the Arab economies where the revolts are taking place are based on «rents» from oil, gas, minerals and tourism, which provide most of the export earnings and state revenues (Financial Times, February 22, 2011, p. 14). These economic sectors are, in effect, export enclaves employing a tiny fraction of the labour force and define a highly specialized economy (World Bank Annual Report, 2009). These export sectors do not have links to a diversified productive domestic economy: oil is exported and finished manufactured goods as well as financial and high tech services are all imported and controlled by foreign multinationals and ex-pats linked to the ruling class (Economic and Political Weekly, February 12, 2011: 11). Tourism reinforces «rental» income, as the sector which provides «foreign exchange» and tax revenues to the class-clan state. The latter relies on state-subsidized foreign capital and local politically connected «real estate» developers for investment and imported foreign construction workers.

Rent-based income may generate great wealth, especially as energy prices soar, but the funds accrue to a class of «rentiers» who have no vocation or inclination for deepening and extending the process of economic development and innovation. The rentiers «specialize» in financial speculation, overseas investments via private equity firms, extravagant consumption of high-end luxury 
goods and billion-dollar and billion-euro secret private accounts in overseas banks.

The rentier economy provides few jobs in modern productive activity; the high end is controlled by extended family-clan members and foreign financial corporations via ex-pat experts; technical and low-end employment is taken up by contract foreign labour, at income levels and working conditions below what the skilled local labour force is willing to accept.

The enclave rentier economy results in a clan-based ruling class which "confounds» public and private ownership: what is «state» is actually absolutist monarchs and their extended families at the top and their client tribal leader, political entourage and technocrats in the middle.

These are «closed ruling classes». Entry is confined to select members of the clan or family dynasties and a small number of «entrepreneurial» individuals who might accumulate wealth servicing the ruling clan-class. The «inner circle» lives off of rental income, secures payoffs from partnerships in real estate where they provide no skills, but only official permits, land grants, import licenses and tax holidays.

Beyond pillaging the public treasury, the ruling clan-class promotes «free trade», id est importing cheap finished products, thus undermining any indigenous domestic start-ups in the «productive» manufacturing, agricultural or technical sector. As a result there is no entrepreneurial national capitalist or «middle class». What passes for a middle class are largely public sector employees (teachers, health professionals, functionaries, firemen, police officials, military officers) who depend on their salaries, which, in turn, depend on their subservience to absolutist power. They have no chance of advancing to the higher echelons or of opening economic opportunities for their educated offspring.

The concentration of economic, social and political power in a closed clan-class controlled system leads to an enormous concentration of wealth. Given the social distance between rulers and ruled, the wealth generated by high commodity prices 
produces a highly distorted image of per-capital «wealth»; adding billionaires and millionaires on top of a mass of low-income and underemployed youth provides a deceptively high average income (Washington Blog, 2/24/11).

\section{Dynamics of rentier rule: Arms and handouts}

To compensate for these great disparities in society and to protect the position of the parasitical rentier ruling class, the latter pursues alliances with multi-billion-dollar arms corporations, and military protection from the dominant imperial power. The rulers engage in «neocolonization by invitation», offering land for military bases and airfields, ports for naval operations, collusion in financing proxy mercenaries against anti-imperial adversaries and submission to Zionist hegemony in the region (despite occasional inconsequential criticisms).

In the middleterm, rule by forceis complemented bypaternalistic handouts to the rural poor and tribal clans; food subsidies for the urban poor; and dead-end make-work employment for the educated unemployed (Financial Times, February 25, 2011: 1). Both costly arms purchases and paternalistic subsidies reflect the lack of any capacity for productive investments. Billions are spent on arms rather than diversifying the economy. Hundreds of millions are spent on one-shot paternalistic handouts, rather than long-term investments generating productive employment.

The "glue» holding this system together is the combination of modern pillage of public wealth and natural energy resources and the use of traditional clan and neocolonial recruits and mercenary contractors to control and repress the population. US modern armaments are at the service of anachronistic absolutist monarchies and dictatorships, based on the principles of $18^{\text {th }}$ century dynastic rule.

The introduction and extension of the most up-to-date communication systems and ultra-modern architecture shopping centers cater to an elite strata of luxury consumers and provides a 
stark contrast to the vast majority of unemployed educated youth, excluded from the top and pressured from below by low-paid overseas contract workers.

\section{Neoliberal destabilization}

The rentier class-clans are pressured by the international financial institutions and local bankers to «reform» their economies: «open» the domestic market and public enterprises to foreign investors and reduce deficits resulting from the global crises by introducing neoliberal reforms (Economic and Political Weekly, February 12, 2011: 11). As a result of «economic reforms» food subsidies for the poor have been lowered or eliminated and state employment has been reduced, closing off one of the few opportunities for educated youth. Taxes on consumers and salaried / wage workers are increased while the real estate developers, financial speculators and importers receive tax exonerations. Deregulation has exacerbated massive corruption, not only among the rentier ruling class-clan, but also by their immediate business entourage.

The paternalistic «bonds» tying the lower and middle class to the ruling class have been eroded by foreign-induced neoliberal «reforms», which combine «modern» foreign exploitation with the existing «traditional» forms of domestic private pillage. The class-clan regimes no longer can rely on the clan, tribal, clerical and clientelistic loyalties to isolate urban trade unions, student, small business and low-paid public sector movements.

\section{The street against the palace}

The «immediate causes» of the Arab revolts are centred in the huge demographic-class contradictions of the clan-class ruled rentier economy. The ruling oligarchy rules over a mass of unemployed and underemployed young workers; the latter involves between 50 to $65 \%$ of the population under 25 years of age (Washington Blog, February 24, 2011). The dynamic «modern» 
rentier economy does not incorporate the newly educated young into modern employment; it relegates them into the low-paid unprotected «informal economy» of the street as venders, transport and contract workers and in personal services. The ultra-modern oil, gas, real estate, tourism and shopping-mall sectors are dependent on the political and military support of backward traditional clerical, tribal and clan leaders, who are subsidized but never «incorporated» into the sphere of modern production. The modern urban industrial working class' small, independent trade unions are banned. Middle class civic associations are either under state control or confined to petitioning the absolutist state.

The «underdevelopment» of social organizations, linked to social classes engaged in modern productive activity, means that the pivot of social and political action is the street. Unemployed and underemployed part-time youth engaged in the informal sector are found in the plazas, at kiosks, cafes, street corner society, and markets, moving around, about and outside the centers of absolutist administrative power. The urban mass does not occupy strategic positions in the economic system; but it is available for mass mobilizations capable of paralyzing the streets and plazas through which goods and services are transported and profits are realized. Equally important, mass movements launched by the unemployed youth provide an opportunity for oppressed professionals, public sector employees, small business people and the self-employed to engage in protests without being subject to reprisals at their place of employment-dispelling the «fear factor» of losing one's job.

The political and social confrontation revolves around the opposite poles: clientelistic oligarchies and de clasé masses (the Arab Street). The former depends directly on the state (military / police apparatus) and the latter on amorphous local, informal, face-to-face improvised organizations. The exception is the minority of university students who move via the internet. Organized industrial trade unions come into the struggle late and largely focus on sectoral economic demands, with some 
exceptions, especially in public enterprises, controlled by cronies of the oligarchs, where workers demand changes in management.

As a result of the social particularities of the rentier states, the uprisings do not take the form of class struggles between wage labour and industrial capitalists. They emerge as mass political revolts against the oligarchical state. Street-based social movements demonstrate their capacity to delegitimize state authority, paralyze the economy, and can lead up to the ousting of the ruling autocrats. But it is the nature of mass street movements to fill the squares with relative ease, but also to be dispersed when the symbols of oppression are ousted. Street-based movements lack the organization and leadership to project, let alone impose a new political or social order. Their power is found in their ability to pressure existing elites and institutions, not to replace the state and economy. Hence the surprising ease with which the US, Israeli and EU backed Egyptian military were able to seize power and protect the entire rentier state and economic structure while sustaining their ties with their imperial mentors.

\section{Converging conditions and the «demonstration effect»}

The spread of the Arab revolts across North Africa, the Middle East and Gulf States is, in the first instance, a product of similar historical and social conditions: rentier states ruled by familyclan oligarchs dependent on «rents» from capital intensive oil and energy exports, which confine the vast majority of youth to marginal informal «street-based» economic activities.

The «power of example» or the «demonstration effect» can only be understood by recognizing the same socio-political conditions in each country. Street power-mass urban movements-presumes the street as the economic locus of the principal actors and the takeover of the plazas as the place to exert political power and project social demands. No doubt the partial successes in Egypt and Tunisia did detonate the movements elsewhere. But they did so only in countries with the same historical legacy, the same 
social polarities between rentier-clan rulers and marginal street labour and especially where the rulers were deeply integrated and subordinated to imperial economic and military networks.

\section{Conclusion}

Rentier rulers govern via their ties to the US and EU military and financial institutions. They modernize their affluent enclaves and marginalize recently educated youth, who are confined to lowpaid jobs, especially in the insecure informal sector, centered in the streets of the capital cities. Neoliberal privatizations, reductions in public subsidies (for food, unemployment subsidies, cooking oil, gas, transport, health, and education) shattered the paternalistic ties through which the rulers contained the discontent of the young and poor, as well as clerical elites and tribal chiefs. The confluence of classes and masses, modern and traditional, was a direct result of a process of neoliberalization from above and exclusion from below. The neoliberal reformers» promise that the «market» would substitute well-paying jobs for the loss of state paternalistic subsidies was false. The neoliberal polices reinforced the concentration of wealth while weakening state controls over the masses.

The world capitalist economic crisis led Europe and the US to tighten their immigration controls, eliminating one of the escape valves of the regimes - the massive flight of unemployed educated youth seeking jobs abroad. Out-migration was no longer an option; the choices narrowed to struggle or suffer. Different studies show that those who emigrate tend to be the most ambitious, better educated (within their class) and greatest risk-takers. Now, confined to their home country, with few illusions of overseas opportunities, they are forced to struggle for individual mobility at home through collective social and political action.

Equally important among the political youth, is the fact that the US, as guarantor of the rentier regimes, is seen as a declining imperial power: challenged economically in the world market by 
China; facing defeat as an occupying colonial ruler in Iraq and Afghanistan; and humiliated as a subservient and mendacious servant of an increasingly discredited Israel via its Zionist agents in the Obama regime and Congress. All of these elements of US imperial decay and discredit encourage the pro-democracy movements to move forward against the US clients and lessen their fears that the US military would intervene and face a third military front. The mass movements view their oligarchies as «third tier» regimes: rentier states under US hegemony, which, in turn, is under Israeli-Zionist tutelage. With 130 countries in the UN General Assembly and the entire Security Council, minus the US, condemning Israeli colonial expansion; with Lebanon, Egypt, Tunisia and the forthcoming new regimes in Yemen and Bahrain promising democratic foreign policies, the mass movements realize that all of Israel's modern arms and 680,000 soldiers are of no avail in the face of its total diplomatic isolation, its loss of regional rentier clients, and the utter discredit of its bombastic militarist rulers and their Zionist agents in the US diplomatic corps (Financial Times, February 24, 2011: 7).

The very socioeconomic structures and political conditions which detonated the pro-democracy mass movements, the unemployed and underemployed youth organized from «the street», now present the greatest challenge: can the amorphous and diverse mass become an organized social and political force which can take state power, democratize the regime and, at the same time, create a new productive economy to provide stable well-paying jobs, so far lacking in the rentier economy? The political outcome to date is indeterminate: democrats and socialists compete with clerical, monarchist, and neoliberal forces bankrolled by the US.

It is premature to celebrate a popular democratic revolution. 
II

WASHINGTON FACES THE ARAB REVOLTS: SACRIFICING DICTATORS TO SAVE THE STATE

To understand the Obama regime's policy toward Egypt, the Mubarak dictatorship and the popular uprising, it is essential to locate it in an historical context. The essential point is that Washington, after several decades of being deeply embedded in the state structures of the Arab dictatorships, from Tunisia through Morocco, Egypt, Yemen, Lebanon, Saudi Arabia and the Palestinian Authority, is attempting to re-orient its policies to incorporate and / or graft liberal-electoral politicians onto the existing power configurations.

While most commentators and journalists spill tons of ink about the «dilemmas» of US power, the novelty of the Egyptian events and Washington's day-to-day policy pronouncements, there are ample historical precedents that are essential to understand the strategic direction of Obama's policies.

\section{Historical background}

US foreign policy has a long history of installing, financing, arming and backing dictatorial regimes which back its imperial policies and interests as long as they retain control over their people.

In the past, Republican and Democratic presidents worked closely for over 30 years with the Trujillo dictatorship in the Dominican Republic; installed the autocratic Diem regime in pre-revolutionary Vietnam in the 1950s; collaborated with two generations of Somoza family terror regimes in Nicaragua; financed and promoted the military coup in Cuba 1952, Brazil 1964, Chile in 1973, and in Argentina in 1976 and the subsequent repressive regimes. When popular upheavals challenged these US backed dictatorships, and a social as well as political revolution appeared likely to succeed, Washington responded with a three track policy: publically criticizing the human rights violations and advocating 
democratic reforms; privately signaling continued support to the ruler; and thirdly, seeking an elite alternative which could substitute for the incumbent, preserve the state apparatus and the economic system, and support US strategic imperial interests.

For the US there are no strategic relationships only permanent imperial interests, namely preservation of the client state. The dictatorships assume that their relationships with Washington are strategic: hence the shock and dismay when they are sacrificed to save the state apparatus. Fearing revolution, Washington has had reluctant client despots, unwilling to move on, assassinated (Trujillo and Diem). Some are provided sanctuaries abroad (Somoza, Batista), others are pressured into power-sharing (Pinochet) or appointed as visiting scholars to Harvard, Georgetown or some other «prestigious» academic posting.

The Washington calculus on when to reshuffle the regime is based on an estimate of the capacity of the dictator to weather the political uprising, the strength and loyalty of the armed forces and the availability of a pliable replacement. The risk of waiting too long, of sticking with the dictator, is that the uprising radicalizes: the ensuing change sweeps away both the regime and the state apparatus, turning a political uprising into a social revolution. Just such a «miscalculation» occurred in 1959 in the run-up to the Cuban revolution, when Washington stood by Batista and was not able to present a viable pro-US alternative coalition linked to the old state apparatus. A similar miscalculation occurred in Nicaragua, when President Carter, while criticizing Somoza, stayed the course, and stood passively by as the regime was overthrown and the revolutionary forces destroyed the US and Israeli trained military, secret police and intelligence apparatus, went on to nationalize US property and develop an independent foreign policy.

Washington moved with greater initiative in Latin America in the 1980s. It promoted negotiated electoral transitions which replaced dictators with pliable neoliberal electoral politicians, who pledged to preserve the existing state apparatus, defend the privileged foreign and domestic elites and back US regional and international policies. 


\section{Lessons from the past and policies in the present}

Obama has been extremely hesitant to oust Mubarak for several reasons, even as the movement grows in number and anti-Washington sentiment deepens. The White House has many clients around the world, including Honduras, Mexico, Indonesia, Jordan and Algeria-who believe they have a strategic relationship with Washington and would lose confidence in their future if Mubarak were dumped.

Secondly, the highly influential leading pro-Israel organizations in the US (AIPAC, the Presidents of the Major American Jewish Organizations) and their army of scribes have mobilized congressional leaders to pressure the White House to continue backing Mubarak, as Israel is the prime beneficiary of a dictator who is at the throat of the Egyptians (and Palestinians) and at the feet of the Jewish state.

As a result the Obama regime has moved slowly, under fear and pressure of the growing Egyptian popular movement. It searches for an alternative political formula that removes Mubarak, retains and strengthens the political power of the state apparatus and incorporates a civilian electoral alternative as a means of demobilizing and de-radicalizing the vast popular movement.

The major obstacle to ousting Mubarak is that a major sector of the state apparatus, especially the 325,000 Central Security Forces and the 60,000 National Guard are directly under the Interior Ministry and Mubarak. Secondly, top Generals in the Army (468,500 members) have buttressed Mubarak for 30 years and have been enriched by their control over very lucrative companies in a wide range of fields. They will not support any civilian «coalition» that calls into question their economic privileges and power to set the political parameters of any electoral system. The supreme commander of the Egyptian military is a longtime client of the US and a willing collaborator with Israel.

Obama is resolutely in favor of collaborating with and ensuring the preservation of these coercive bodies. But he also needs to 
convince them to replace Mubarak and allow for a new regime that can defuse the mass movement that is increasingly opposed to US hegemony and subservience to Israel. Obama will do everything necessary to retain the cohesion of the state and avoid any splits that might lead to a mass movement — soldier alliance that could convert the uprising into a revolution.

Washington has opened talks with the most conservative liberal and clerical sectors of the anti-Mubarak movement. At first it tried to convince them to negotiate with Mubarak-a dead end position that was rejected by all sectors of the opposition, top and bottom. Then Obama tried to sell a phony "promise» from Mubarak that he would not run in the elections, nine months later.

The movement and its leaders rejected that proposal also. So Obama raised the rhetoric for «immediate changes», but without any substantive measures backing it up. To convince Obama of his continued power base, Mubarak sent his formidable thug-lumpen secret police to violently seize the streets from the movement. A test of strength: the Army stood by; the assault raised the ante of a civil war, with radical consequences. Washington and the EU pressured the Mubarak regime to back off-for now. But the image of a pro-democracy military was tarnished, as killings and injuries multiplied in the thousands.

As the pressure of the movement intensifies, Obama isbeing cross-pressured by the pro-Mubarak Israel Lobby and its Congressional entourage on the one hand, and on the other by knowledgeable advisors who call on him to follow past practices and move decisively to sacrifice the regime to save the state while the liberal-clerical electoral option is still on the table. But Obama hesitates and like a wary crustacean, he moves sideways and backwards, believing his own grandiloquent rhetoric is a substitute for action, hoping that sooner or later, the uprising will end with Mubarakism without Mubarak: a regime able to demobilize the popular movements and willing to promote elections which result in elected officials following the general line of their predecessor. 
Nevertheless, there are many uncertainties in a political reshuffle: a democratic citizenry, $83 \%$ unfavourable to Washington, will possess the experience of struggle and freedom to call for a realignment of policy, especially to cease being a policeman enforcing the Israeli blockage of Gaza, and providing support for US puppets in North Africa, Lebanon, Yemen, Jordan and Saudi Arabia. Secondly free elections will open debate and increase pressure for greater social spending, the expropriation of the seventy-billion-dollar empire of the Mubarak clan and the crony capitalists who pillage the economy. The masses will demand a reallocation of public expenditure from the overblown coercive apparatus to productive, job generating employment. A limited political opening may lead to a second round, in which new social and political conflicts will divide the anti-Mubarak forces, a conflict between the advocates of social democracy and elite backers of neo-liberal electoralism. The anti-dictatorial moment is only the first phase of a prolonged struggle toward definitive emancipation not only in Egypt but throughout the Arab world. The outcome depends on the degree to which the masses develop their own independent organization and leaders.

\section{III \\ UNREST AND CHANGE IN THE MIDDLE EAST: DISPATCHES FROM THE FRONTLINE OF A CLASS WAR IN EGYPT}

To properly grasp the political dynamics of capitalist development means that we need to think of «politics» and «economics», which in liberal and bourgeois discourse is conceived of as separate spheres, as interconnected and part of the same struggle. For example, to claim that the Egyptian demonstrators were primarily concerned with Hosni Mubarak and so-called «political freedoms»-the dominant narrative of US and other world leaders and much of the corporate media coverage-is to distort and misread the nature of these protests. Clearly, as noted by Adam Hanieh in his penetrating analysis of recent developments in Egypt, «the protests 
have encompassed a wide variety of social layers with different demands, but their overall logic is inextricably tied to broader questions of capitalism in the Middle East». These questions are neither solely «political» nor «economic» but revolve primarily around which class rules Egypt and in whose interest the Egyptian state functions. They include: $a$ ) the global economic crisis and the nature of neoliberalism in Egypt, b) Egypt's role in sustaining patterns of US domination in the Middle East. The nature of Mubarak's rule, Hanieh argues, cannot be separated from these questions, which is «why the struggle against political despotism is inevitably intertwined with the dynamic of class struggle».

An illustration of the class character of these popular uprisings is their link to the chain of protests that have erupted over the last three years in the wake of the global economic crisis. This is the Arab world's response to that crisis, which confounds the dominant narrative that the economic crisis was largely confined to the advanced capitalist core and that the so-called «emerging markets» had escaped the worst effects. However, Hanieh notes, «decades of neoliberalism have tied the Egyptian economy into the capitalist world market in a very uneven fashion and, as a consequence, the crisis was to have a devastating impact on the majority of the country's population».

There have been a variety of mechanisms through which this transmission of crisis has taken place. First, the Middle East (and particularly the North Africa region) is highly dependent upon exports to Europe and these have fallen precipitously due to the drop in demand that followed economic contraction. World Bank figures show that Egypt's year-on-year growth rates of merchandise exports to the EU dropped from 33\% in 2008 to $-15 \%$ by July 2009 (World Bank, 2010: 142). Similarly, Tunisia and Morocco saw the total value of their world exports fall by 22 and $31 \mathrm{t}$ respectively in 2009-leading the World Bank to note that these countries were facing the worst recessions in six decades (ibid).

A second transmission mechanism has been the curtailment of worker remittances on which the Middle East is highly dependent. 
In the case of Egypt, workers tend to migrate to the Gulf countries, Libya and Jordan. For the rest of North Africa, this labour migration tends to be toward Europe. Egypt is the largest recipient of remittances in the Middle East, representing approximately $5 \%$ of national GDP. With the mass layoffs that continue to characterize the global crisis-particularly in sectors such as constructionremittances have fallen rapidly. Egypt experienced a massive contraction of $18 \%$ in remittances from 2008 to 2009 . For a region where these flows form the basic survival mechanism for millions of people, the decline has had devastating consequences.

These effects also need to be placed alongside the other more recent feature of the crisis: the spiraling cost of basic food and energy items. This rising commodity inflation is another aspect of the crisis itself, partially resulting from the large quantities of extra cash pumped into the system to ameliorate the crisis in the core countries, particularly the US program of «quantitative easing» (McNally, 2011). Once again, Hanieh argues, the effects have been magnified in much of the Middle East. In Egypt, he notes, annual food price inflation accelerated to 18.9\% in January 2011 from $17.2 \%$ in December. These rapid increases in prices are essentially a form of severe wage cuts for those segments of the population compelled to spend most of their income on basic items.

\section{Neoliberalism}

Any mapping of the crisis needs to go beyond the immediate results of global slowdown and be situated within the three decades of neoliberal «reforms» that Egypt, together with other countries and regions on the periphery of the system, has experienced. What neoliberalism has done among other things is to make the country much more vulnerable to the crisis itself-massively widening the levels of inequality and, simultaneously, undermining potential mechanisms of social support. Precisely because of these outcomes of neoliberalism, the effects of the crisis were sharply concentrated on the most vulnerable layers of Egyptian 
society. At the same timed this expresses the essential class character of the neoliberal project, a tiny elite benefited enormously from these economic measures. In Mexico, for example, in another part of the world but with substantially the same experience of neoliberalism, the super-rich, a small group of 11 billionaires that effectively stage-managed if not substantively benefitted from the government's response to the "global financial crisis», came out of the crisis with a $127 \%$ increase in the value of their net worth, representing $12.4 \%$ of the GDP (La Jornada, March 10, 2011: 31). The personal fortune of Carlos Slim, at the very top of Forbes' list of the world's richest, increased 38\% over the course of the last year. By the same token, the poor, estimated conservatively at $44 \%$ of the population, suffered a severe deterioration in their social condition as a result of the crisis,- - having to confront a sharp rise in the cost of many basic commodities under precarious working conditions and falling incomes.

This reading of Egypt's-and Mexico's-experience runs directly counter to the account of international financial institutions such as the IMF and World Bank. The IMF, for example, in February 2010, claimed that Egypt had been «resilient to the crisis' because «sustained and wide-ranging reforms since 2004 had reduced fiscal, monetary, and external vulnerabilities, and improved the investment climate» (quoted by Hanieh). According to the IMF, as quoted by Hanieh, the Egyptian government's successful implementation of neoliberalism had «bolstered the economy's durability and provided breathing space for appropriate policy responses» (IMF, 2010).

The IMF finds evidence for Egypt's resilience in the relatively high GDP growth rates that the country has managed to sustain. From 2006 to 2008 growth was around 7\% annually, and in 2009, when much of the world was experiencing negative GDP growth, Egypt recorded a growth rate of $4.6 \%$. But, as Hanieh notes, this GDP-centric account assesses a country's health on the basis of aggregate macro-statistics, on the assumption that a growth trend at the aggregate level is good for the population as a whole. 
In fact it hides the reality that capitalism is an exploitative system, and the outcome of the unfettered market typically means that overall growth results in the widening of inequality. ${ }^{1}$ It is, in other words, a statistical expression of the «trickle-down effect». Egypt is a perfect example of the reality behind this myth: neoliberalism has produced rapid growth rates but, simultaneously, it has led to worsening living standards for the majority of the population and the increased concentration of wealth in the hands of a tiny minorit)

According to official government statistics poverty increased from 20 to $23.4 \%$ from 2008 to 2009 . This in itself is a significant increase, but official statistics need to be approached with a large degree of skepticism. The official poverty line is set at an absurdly low rate, when in fact some $40 \%$ of Egyptians live on less than $\$ 2$ per day. The official unemployment rate is recorded at around $9 \%$, but again the reality is completely different-more than half of those outside of agriculture are found in the «informal sector» and are not properly recorded in the unemployment statistics. As in so many other places on the capitalist periphery, these informal workers live in a society that lacks any decent social provisions for education, healthcare or broader welfare. It is estimated, for example, that one-third of the Egyptian population is illiterate. The demographic question also looms large here. In a country where the leadership consists of men in their 80s, youth apparently make up more than $90 \%$ of the jobless.

The onset of neoliberalism in Egypt is associated with the series of policy measures known as infitah (opening) that were launched in the 1970s under President Anwar Sadat. After Mubarak came to power following Sadat's assassination, successive governments continued the policy trajectory set by infitah. There were two prongs to this policy, particularly as it unfolded under the aegis of an IMF structural adjustment program in 1990-91. First, a series of policies began to transform social relations in the rural areas. In

1 See, for example, the assessment of neoliberal «pro-growth» policies provided by ECLAC (2010) in the case of Latin America. 
1992, Law 96 of the Egyptian Peoples' Assembly liberalized agricultural rents and allowed for the eviction of tenants by landowners after a five-year transitional period. Rents were raised threefold and-with the encouragement of international financial institutions such as the IMF and World Bank, and US government bodies such as USAID-Egyptian agriculture shifted toward the type of export-oriented production that typifies much of African agriculture today (Bush, 2004). Hundreds of thousands of Egyptians lost their ability to survive on the land and streamed into the informal sector of urban centers, particularly, but not only, into Cairo. ${ }^{2}$

Second, with the policy of privatization, a vital component of the neoliberal reform agenda, state employment was cut back dramatically. Of a total of 314 state enterprises, 209 were privatized by 2005 , leading to a massive displacement of public sector workers, and with it a further weakening of the struggling labour movement (Joya, 2008). The number of workers in these public sector companies was halved from 1994 to 2001. In the banking sector, nearly $20 \%$ of the banking system was transferred from public control to the private sector. The consequence of this wave of privatization, hailed by the IMF in 2006 as having «surpassed expectations» (IMF, 2010), was a massive downgrading of working conditions and the further impoverishment of wide layers the Egyptian population. This was also a contributing factor to the expansion of the army of informal workers that characterize Egyptian cities and that have played such a critical role in the recent uprising.

It is in response to these neoliberal measures-and the complicity of the official state-linked trade union movement-that independent forms of worker organizing emerged in an important wave of strikes in 2006-08. During 2006 there were 220 major strikes involving tens of thousands of workers in the largest strike wave that Egypt had seen in decades (Allison, 2007). These strikes linked up with peasant movements, which aimed at resisting the loss of

2 For a review of similar developments in Mexico and other parts of Latin America see Delgado Wise and Márquez Covarrubias (2008). 
land due to the neoliberal measures described above. These earlier forms of organization and struggle, according to Hanieh (2011) and others, have been a key element to the historical experiences underpinning the current wave of protests.

Accompanying these neoliberal measures was its corollary: the concentration and centralization of wealth in the hands of a tiny layer of the country's elite. As Tim Mitchell (1999) has described, a key feature of the 1990-91 IMF structural adjustment was a transfer of wealth from the public to the private sector, and from the middle and working classes to the rich and the wellto-do. The result was the strengthening of a handful of massive conglomerates such as the Osman, Bahgat, and Orascom Groups, whose activities stretch across construction, import/export, tourism, real estate and finance (Mitchell, 1999). It was this class that substantively benefited from the privatization process, the access to cheap labour, the government contracts, and the other forms of largesse distributed through the channels of the state.

So while the outrage at the wealth of Mubarak and the state officials associated with his regime is well deserved, we should not forget that Mubarak-and the Egyptian state as a whole-represented an entire capitalist class. The result of neoliberalism was the enrichment of a tiny elite concurrent with the immiseration of the vast majority. However, as Hanieh (2011) correctly notes, this is not an aberration of the system-a kind of «crony capitalism» as some financial commentators have described it-but precisely a normal feature of capitalist accumulation replicated across the world.

The repressive apparatus of the Egyptian state was aimed at ensuring that the lid was kept on any social discontent arising from these worsening conditions. In this sense, the struggle against the effects of the economic crisis would inevitably be compelled to confront the dictatorial character of the regime. 


\section{The regional dimension of capitalist development}

The series of uprisings in the Arab world cannot be understood without situating it within the regional context. Once again, there is the intertwining of the political and economic. For one thing, US policy in the Middle East is aimed, first and foremost, at keeping the oil and petro-dollar-rich Gulf states under its influence. This does not mean that the US wants to directly own these oil supplies but rather that it wants to ensure that the oil supplies remain outside of the democratic control of the people of the region. The nature of global capitalism and the dominant position of the US state within the world market rest significantly upon its control over the Gulf region. As Hanieh notes in his review of political developments in the region, any move toward a broader democratic transformation of the region could potentially threaten US interests and power at a global level. This is why the US has so strongly supported the dictatorships that rule the Gulf states and also why the majority of the labour in the Gulf is performed by temporary migrant workers who lack all citizenship rights and can be deported at any sign of discontent.

All other relations between the US and other countries in the region are subordinated and linked to this goal of US hegemony over the Gulf region. This includes the US-Israel relationship. The US sees Israel as a key pillar of its overall Middle East policy: it is an ally that is fully dependent upon US military and political support and can always be relied upon to act against the interests of the Arab masses. Precisely because Israel has its origins as a settlercolonial state founded upon the dispossession of the Palestinian people, it is seen as a more stable and steadfast pillar of US power than any of the Arab dictatorships that are exposed to the threat of popular revolt. This is why the interests of Israel and the Arab dictatorships are coincident, not opposed to one another, as was so clearly illustrated in the recent uprisings of both Tunisia and Egypt.

Beyond the Gulf states and Israel, the third pillar of US power in the region is reliance upon autocratic leaders such as Mubarak. 
But behind Mubarak (as with his predecessor Sadat) is the Egyptian military. US linkages to Egypt have largely been constructed through the military and this is one of the key reasons why the military plays such a dominant role in the Egyptian state. The vast amount of military aid that Egypt receives from the US (around \$1.4-billion annually) is well known, as is the role that the military has played in supporting US policy across the Middle East (the current head of the Supreme Council of the Armed Forces, Mohamed Tantawi, fought alongside US troops in the 1991 Gulf War). The highest ranks of Egypt's military are so closely connected to the capitalist class as to be an integral part of it with significant economic interests that overlap with the state and private sector. Precisely because of the military's central role in sustaining US power regionally, and its own stake in the reproduction of Egyptian capitalism, the belief of some that the Egyptian military is «part of the people» or «neutral and above politics» is illusory, to say the least (Achcar, 2011).

Over the last two decades the linkages between the political and economic configuration of US power in the Middle East has become even more explicit. United States policy has followed a two-pronged track that ties neoliberalism with the normalization of economic and political relations between the Arab world and Israel. The broader goal has been the creation of a single economic zone from Israel to the Gulf states, linked under the dominance of the US. One of the mechanisms for reaching this goal has been a series of Free Trade Agreements (FTAs) signed between the US and Arab states in the region (Morocco, Bahrain, Oman, Jordan, and Egypt) that, over time, would be knitted together in a single free trade area enabling the unfettered flow of capital and goods across the region (Hanieh, 2008).

The bond between normalization and neoliberalism is powerfully illustrated in the character of these US bilateral FTAs, which include as part of their conditions a requirement to lift any boycott or refusal to trade with Israel (Hanieh, 2011). In the case of Egypt (and Jordan) the link is more advanced than any other 
state in the region, and is best shown in the so-called Qualified Industrial Zones (QIZs). These QIZs provide duty free access to the US market for Egyptian exports. But they contain the remarkable provision that a certain proportion of imports (around 12\%) must be Israeli in order to qualify for duty-free status. The Egyptian QIZs are concentrated in the textile sector, with 770 companies operating in the zones at the end of 2009. In the few short years of their existence they have grown to be a significant weight in Egyptian exports to the United States. Egyptian exports from the QIZs grew at an incredible 57\% annually between 2005 and 2008, more than ten times the rate of Egypt's exports to the US as a whole (Kotschwar and Schott, 2008: 20). In 2010, QIZs exports made up more than $40 \%$ of the value of all of Egypt's exports to the United States. ${ }^{3}$

It is noteworthy that Egyptian activists have raised the demand during the recent uprising to shut down these QIZs. It would be a further powerful step to open the books of these QIZs-accurate and factual information about their operations are notoriously hard to come by and it would be a great service of the Egyptian people to reveal them to the world. It should also be noted that similar QIZs exist in the Jordanian context-with the added twist that many of the workers in the Jordanian QIZs are severely exploited migrants from Asia.

These regional processes thus further confirm the impossibility of separating the «economic» and «political» aspects of the current uprisings. The demand to cut ties with Israel and abrogate the regional agreements signed by Sadat and Mubarak are partand-parcel of resisting the logic of neoliberalism and US power in the region. The authoritarian nature of the state is a direct outcome of these regional processes and, for this reason, if it is to be successful, the struggle for greater political freedom must inevitably take up questions of confronting US dominance of the region and the particular role Israel plays in sustaining that dominance.

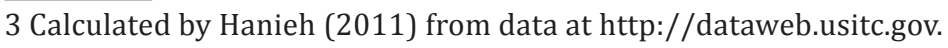




\section{Conclusion}

The story that has been told in much of the mass media and reinforced by the carefully-worded rhetoric of US and European officials is that these demonstrations have primarily been a struggle to overthrow individual tyrants. There is, of course, a one-sided truth to this: protestors have taken aim at the individual personages of Ben Ali and Mubarak. But the claim that this is a struggle for «democracy» acts to obfuscate more than clarify what these uprisings are about. Two-thirds of the Egyptian population is under the age of 30 . This means that the vast majority of the Egyptian population has not only spent their entire lives under the rule of Hosni Mubarak; they have also endured a very brutal form of neoliberal capitalism. The demonstrations were a direct result of the naked class power embodied by Mubarak's rule. This was, Hanieh notes, graphically illustrated in the way in which the capitalist class essentially fled the country in the first few days of the uprising. ${ }^{4}$

The anti-democratic character of so many of the regimes in the Arab world is not accidental or a question of individuals or culture, but rather the political form of capitalism in the region. It is the way that capitalism necessarily functions in a society marked by astonishingly high levels of inequality, and which is located in a region that is so central to the constitution of US power at a global level. In this regard, the Middle-East and North Africa region can be compared to Latin America, a region with even wider and deeper levels of social inequality in the distribution of wealth and income. Again, there was nothing accidental or contingent about the succor and support given by the US to every military dictatorship or authoritarian regime that dominated the Latin American political landscape in the years from the 1950s to the 1970s. For this reason, the demand for democratic expression in societies

4 Hanieh (2011), in this regard, cites reports in the early days of the uprising that Egypt's largest business owners flew out on 19 planes to Dubai where they hoped to ride out the storm of the uprising. 
characterized by decades of atrophied public space is one facet of a much broader struggle that pivots around the question of class. Mubarak, for example, was but the public face of a military government, and removing that face does not change the character of military rule or the way in which that rule sustains the dominance of a particular class. The role of the Egyptian military cannot be decisively reformed while leaving the structure of capitalism and its regional linkages unchallenged.

This analysis runs precisely opposite to the rhetoric of Obama and other world leaders that whitewashes the West's decades-long support for Mubarak and other Arab autocrats, and that claims that the uprisings in the region by the citizens against their government is simply a question of political «transition». Thus there is a desperate attempt now by local elites and the US government, and all their regional allies (including Israel), to separate the "political» and "economic» characteristics of the popular struggle and confine the struggle to simply a question of democratic transition - to elude thereby any deeper questioning of the regimes in place. This is clearly demonstrated by media reports on 14 February that the Egyptian military would outlaw strikes and other forms of independent worker organizing. But the struggle against the Egyptian dictatorship and the other authoritarian regimes in the region remains, in essence, a class struggle.

\section{IV \\ THE EURO-US WAR ON LIBYA: \\ OFFICIAL LIES AND MISCONCEPTIONS OF CRITICS}

One of the basic flaws of the arguments of critics of Euro-US wars is their resort to clichés, generalizations and arguments without any factual bases. The most common line on the US-Euro war on Libya is that it's «all about oil» — the seizure of oil wells. On the other hand, Euro-US government spokespeople have defended the war by claiming it is about «saving civilian lives facing genocide»; an act of «humanitarian intervention». 
Following the lead of their imperial powers, most of what passes for the Left in the US and Europe, ranging from social democrats, Marxists, Trotskyists and other assorted progressives claim to see and support a revolutionary mass uprising and not a few call for active intervention by the imperial powers, or the same thing, the UN, to presumably help the «social revolution» defeat the Gaddafi dictatorship.

These claims and variations of these arguments are totally without substance and belie the true nature of US-UK-French imperial power, based on rising militarism as evidenced in all the ongoing wars over the past decade (Iraq, Afghanistan, Somalia, etc.). What is revealing in the context of militarist intervention in Libya is that all the major countries which refused to engage in the War are motivated by a different type of global expansion: economic and market forces. China, India, Brazil, Russia, Turkey, Germany, the most dynamic capitalist countries in Asia, Europe and the Middle East are, in part, all opposed the self-styled «allied» military response because they see (with solid reasons) no threat to their security, an open door for access to oil, a favorable investment climate and no signs of any progressive democratic outcome among the disparate elites competing for power and Western favor among the media labeled «rebels».

\section{Myth 1: Humanitarianism of the West}

The principal imperial powers and their mass-media mouthpieces claim they are militarily assaulting Libya for «humanitarian reasons». Their recent past and present history suggests the contrary. Interventions in Iraq resulted in over a million killings, four million displaced civilians and the mass destruction of an entire civilization including water, electricity, research centers, museums, ad nauseum.

Similar outcomes resulted from the invasion of Afghanistan. What was dubbed a humanitarian intervention resulted in a human catastrophe. In the case of Iraq the road to imperial barbarism 
began with «sanctions», progressed to «no fly zones», then to partition, then to invasion and occupation and the unleashing of sectarian tribal warfare among the «liberated» rebel paramilitary death squads. Equally telling was the imperial assault against Yugoslavia, also justified as a «humanitarian war» against a "genocidal regime», which led to the 40 day massive bombing campaign and destruction of Belgrade and other major cities, the imposition of a gangster terrorist regime (KLA) in the separatist province of Kosova and a huge US military base in the latter.

The bombing of Libya has destroyed major civilian infrastructure, airports, roads, seaports, communication centers as well as military targets. The sanctions and military attacks have driven out scores of multi-national corporations and exodus of hundreds of thousands of African, Middle Eastern and North African immigrant workers and technicians, devastating the economy and creating massive long-term unemployment. Moreover, following the logic of previous imperial military interventions, the seemingly «moderate» call to patrol the skies via «no fly zone», leads directly to bombing terrestrial civilian as well as military targets, onward to overthrowing the government. The imperial warmongers attacking Libya, like their predecessors, are not engaged in anything remotely resembling a humanitarian gesture: they are destroying the civilian lives they purport to be saving - as was the case in Vietnam earlier.

\section{Myth 2: War for Oil or Oil for Sale?}

One of the most opt repeated cliché by the Left or at least many leftists is that the imperial invasion is about «seizing control of Libya's oil and turning it over to their multinationals». The facts on the ground tell us a different story: the multinational oil companies of Europe, Asia, the US and elsewhere have already «taken over» millions of acres of Libyan oil fields, some are already pumping and exporting oil and gas and are reaping hefty profits for almost the better part of a decade. MNC «exploitation by invitation» - from 
Gaddafi to the biggest oil companies - is an ongoing process from the early 1990s to the present day. The list of foreign oil majors engaged in Libya exceeds that of most oil producing countries in the entire world. They include British Petroleum with a seven-year license on two concessions with one-billion dollars in planned investments. Each concession involves BP exploiting enormous areas of Libya, one the size of Kuwait, the other the size of Belgium (Lybiaonline.com). Five Japanese firms, (including Mitsubishi and Nippon Petroleum), Italy's Eni Gas, British Gas and Exxon Mobil secured exploration and exploitation contracts in October 2010. In January 2010, Libya's oil concessions mainly benefited US oil companies, especially Occidental Petroleum. Foreign multinationals gaining contracts also include Royal Dutch Shell, Total (France), Oil India, CNBC (China), Indonesia's Pertamina and Norway's Norsk Hydro (BBC News, 10/03/2005).

Despite sanctions imposed by Reagan in 1986, Halliburton has worked on billion-dollar gas and oil projects since the 1980s. During former Defense Secretary Cheney's tenure as CEO of Halliburton, he led the fight against sanctions, arguing that «as a nation (there is) enormous value having American businesses engaged around the world' (Halliburtonwatch.org). Sanctions against Libya were lifted under Bush in 2004. During the past decade, Gaddafi invited more foreign companies to invest in Libya than any other regime in the world. Clearly, with all the European and US imperial countries already exploiting Libya oil on a massive scale, the argument that the «war is about oil» does not hold water or oil!

\section{Myth 3: Gaddafi is a Terrorist}

In the run-up to the US military assault, Treasury led by Israeli super-agent Stuart Levey, authored a sanctions policy freezing \$30 billion dollars in Libyan assets claiming Gaddafi was a murderous tyrant (Washington Post, 3/24/11). Yet precisely seven years earlier, Cheney, Bush and Condoleezza Rice took Libya off the list of 
terrorist regimes and told Levey and his minions to lift sanctions. Every major European power followed suite: Gaddafi was welcomed in European capitals, prime ministers visited Tripoli and Gaddafi reciprocated by unilaterally dismantling his nuclear and chemical weapons programs (BBC, 9/5/2008). Gaddafi bent over backwards in co-operating with Washington's campaign against groups, movements and individuals on Washington's arbitrary «terror list» arresting, torturing and killing $\mathrm{Al}$ Qaeda suspects; expelling Palestinian militants and criticizing Hezbollah, Hamas and other Israeli adversaries. The United Nations Human Rights Committee gave Gaddafi a clean bill of health. Western elites welcomed Gaddafi's political turnabout but it did not save him from a massive military assault. Neoliberal reforms, political apostasy, anti-terrorism, eliminating weapons of massive destruction, all weakened the regime, increased its vulnerability and isolated it from any consequential anti-imperialist allies. Gaddafi's concessions made his regime an easy target for militarists in Washington, London and Paris.

\section{Myth 4: The revolutionary masses in waiting}

The Left, including the principal social democratic, green and even left socialist parties of Europe and the US, tail-ending their imperial mentors, and susceptible to the massive media propaganda campaign demonizing Gaddafi, justified their support for military intervention, in the name of the "revolutionary people», the peace-loving masses «fighting tyranny» and organizing popular militias to "liberate the country». Nothing could be further from the truth.

The root base of the armed uprising is Benghazi, a hotbed of tribal backers and clients of the deposed King Idris who ruled with an iron fist over a semi-feudal backward state, who gave the US one of its biggest air bases (Wheeler) in the Mediterranean basin. Among the feuding leaders of the «transitional council» (who purport to lead but have few organized followers) are neo-liberal expats who promoted the Euro-US military invasion and can only 
envision coming to power on the bases of Western missiles. They look forward to dismantling the public oil companies engaged in joint ventures with foreign multinationals. All independent observers report the lack of any clear reformist let along revolutionary organization or social-political democratic movement.

The armed militias in Benghazi are reportedly more active in rounding up, arresting and executing any members of Gaddafi's national network of civilians active in his «revolutionary committees», arbitrarily labeling them «fifth columnists» than in engaging the regimes armed forces. The top leaders of the "revolutionary» masses in Benghazi are two top recent defectors of what the Left dubs Gaddafi's «murderous regime», Mustafa Abdul Jalil, a former Justice minister (who prosecuted dissenters up to the day before the armed uprising), Mahmoud Jebril a top Gaddafite neoliberal prominent in inviting multi-nationals to take over the oil fields (FT, March 23, 2011, p. 7) and Ali Aziz al-Eisawa, Gaddafi's former ambassador to India who jumped ship when it looked like the uprising would succeed. These self-appointed leaders of the «rebels» are staunch backers of Euro-US military intervention just as they previously were long-term backers of Gaddafi's dictatorship and promoters of MNC takeovers of oil and gas fields. The heads of the «rebels» military council is Omar Hariri and General Abdul Fattah Younis former head of the Ministry of Interior, both with long histories (since 1969) of repressing any democratic movements. It is not surprising that these top level military defectors have been totally incapable of arousing their troops, conscripts, to engage the loyalist forces backing Gaddafi and all look forward to riding the coattails of the Anglo-US-French armed forces.

The absence of the minimum of democratic credentials among the leaders of the anti-Gaddafi rag-tag forces is matched by their abject dependence and subservience to the imperial armed forces to bring them to power. Their abuse and persecution of immigrant workers from Asia, Turkey and especially sub-Sahara Africans, their false accusations that they are suspected «mercenaries», augurs ill for any possible new democratic order, or the revival of an economy 
dependent on immigrant labor, any vestige of a unified country and anything resembling a national economy.

The composition of the self-appointed leadership of the «National Transitional Council» is neither democratic nor nationalist, nor capable of uniting the country. Least of all are they capable of creating jobs lost by their armed power grab and sustaining the paternalistic welfare program and the highest per-capita income in Africa.

\section{Myth 5: Libya and Al Qaeda}

The greatest geographical concentration of $\mathrm{Al}$ Qaeda terrorists is precisely in the areas dominated by the «rebels» (Cockburn, Counterpunch, March 24, 2011). For over a decade Gaddafi, in line with his embrace of the Bush-Obama «anti-terrorist» agenda, has been in the forefront of the fight against Al Qaeda. They have now enlisted in the ranks of the «rebels» fighting the Gaddafi regime. Likewise, the tribal chiefs, fundamentalist clerics and monarchists in the East have been active in fighting a «holy war» against Gaddafi and welcome arms and air cover from the AngloFrench-US «crusaders», just as the Taliban and the Islamic fundamentalists welcomed military support from the Carter-Reagan White House to overthrow a secular regime in Afghanistan. The imperial intervention is based on «alliances» with the most retrograde forces in Libya, with uncertain outcomes as to the future composition of the regime, and the prospects for political stability allowing Big Oil to return and exploit energy resources.

\section{Myth 6: Genocide or armed civil war}

Unlike all ongoing mass popular Arab uprisings, the Libyan conflict began as an armed insurrection, directed at the violent seizure of power. Unlike other autocratic rulers, Gaddafi had secured a mass regional base among a substantial sector of the population on the bases of a well-financed welfare and housing program. Violence is 
inherent in any armed uprising and once one picks up the gun and tries to seize power, there is no basis for claiming one's «civil rights» are being violated. The rules of warfare come into play, including the protection of non-combatants / civilians, as well as respect for the rights and protection of prisoners of war.

The unsubstantiated Euro-US claims of «genocide» amplified by the Western mass media and parroted by «left» spokespersons are contradicted by the daily reports of single and double digit deaths and injuries, resulting from urban violence on both sides, as control of cities and towns shifts between one side and the other.

Truth is the first casualty of civil war and both sides have resorted to monstrous fabrications of victories, casualties, demons and angels.

The fact of the matter is that this conflict began as a civil war between two sets of elites: an established paternalistic burgeoning neoliberal autocracy with substantial popular backing and on the other, a western imperialist financed and trained elite backed by an amorphous group of regional tribal, clerical and neo-liberal professionals lacking democratic and nationalist credentials

\section{Conclusion}

If not humanitarianism, oil or democratic values, what is the driving force of Euro-US imperial intervention?

A clue is in the selective bases of armed intervention. In Bahrain, Saudi Arabia, Yemen, Jordan, Qatar, Oman, ruling autocrats allied with and backed by Euro-US imperial rulers' arrest and murder peaceful protestors, with impunity. In Egypt and Tunisia, the US financially backs a conservative self-appointed civil-military junta, to block a profound democratic, nationalist, social transformation in order to facilitate neoliberal economic «reforms» run by proimperial electoral officials. While liberal critics accuse the West of «hypocrisy» and «double standards» in bombing Libya but not the Gulf butchers, in reality the imperial rulers are using the same imperial standards in each region. They defend autocratic strategic 
client regimes where they possess air force and naval bases, run intelligence operations and logistic platforms to pursue ongoing wars in Iraq and Afghanistan and to threaten Iran. They attack Libya because it still refuses to collaborate with Western military operations in Africa and the Middle East.

The key point is that while Libya allows most of the big US-European oil multinationals to plunder its oil wealth, it does not yet constitute a strategic geopolitical imperial asset. As we have noted in previous essays, the driving force of US empire building is military power, not economic. In fact, billion-dollar economic interests were sacrificed in setting up sanctions against Iraq and Iran; the Iraq war shut down most oil exploitation for over a decade.

The Washington-led assault on Libya - the majority of air sorties and missiles are carried out by US warplanes and submarines- is part of a general counter-attack against the most recent Arab popular pro-democracy movements. The West is backing the repression of pro-democracy movements throughout the Gulf; it is financing the pro-imperial, pro-Israel Egyptian junta; it is intervening in Tunisia to ensure that any new regime is "correctly aligned». It backs Algerian despotism and Israel's daily assaults on Gaza. And now in Libya, it backs an uprising of ex-Gaddafites and right-wing monarchists who promise to militarily align with the US-European empire builders.

Dynamic market-driven global and regional powers refuse to join in this conflict, which jeopardizes their access to oil, including current large-scale exploitation of energy sources under Gaddafi. Germany, China, Russia, Turkey, India and Brazil are growing at fast rates by exploiting new markets and natural resources, while the US, English and French spend billions in wars that destabilize markets and foment long-term wars of resistance. They recognize that the «rebels» are not capable of a quick victory, or of creating a stable environment for long-term investments. The «rebels» in power would become political clients of their militarist imperial mentors. Moreover, the military thrust of the imperial invaders has serious consequences for the emerging market economies. 
The US supports holy-roller rebels in China's Tibetan province and Uyghur separatist «rebels» elsewhere. Washington and London back separatists in the Russian Caucuses. India is wary of US military support for Pakistan and its claims on Kashmir. Turkey opposes Kurdish separatists backed by US-supplied arms to their Iraqi counterparts.

The Libyan precedent of imperial armed invasion on behalf of separatist clients bodes trouble for the market-driven emerging powers. It is an ongoing threat to the burgeoning Arab freedom movement, and the death knell to the US economy; three wars can break the budget sooner rather than later. Most of all, the invasion undermines efforts by Libya's democrats, socialists and nationalist to free the country from dictatorship and imperial-backed reactionaries.

\section{REFERENCES}

AcHCAR, Gilbert (2011), «Whither Egypt?» The Bullet, No. 459, 7 Febuary. Allison, Jamie (2007), «Wave of struggle shakes Egyptian regime», Socialist Worker, 7 April.

Bush, Ray (2004), «Civil Society and the Uncivil State Land Tenure Reform in Egypt and the Crisis of Rural Livelihoods», UNRISD Programme Paper, No. 9, May.

CoCKBURN, Patrick (2011), «Why are they making wear on Libya?» Counterpunch, March 24.

Delgado Wise, Raúl and Humberto Márquez Covarrubias (2008), «Capital Restructuring, Development and Labour Migration: the Mexico-US Case», Third World Quarterly, 29 (7), pp. 1359-1374.

ECLAC (2010), Time for Equality: Closing Gaps, Opening Trails (Santiago: UN). Hanieh, Adam (2008), «Palestine in the Middle East: Opposing Neoliberalism and US Power», The Bullet, No. 125, 15 July.

(2011), «Egypt's Uprising: Not Just a Question of Transition», The Bullet, No. 462, February 14.

IMF (2010), Arab Republic of Egypt; 2010 Article IV Consultation Mission, Concluding Statement, 16 February 2010. 
JoYA, Angela (2008), «Egyptian Protests: Falling Wages, High Prices and the Failure of an Export-Oriented Economy», The Bullet, No. 111, 2 June. KoTschwaR, Barbara and Jeffrey J. Schott (2008), Reengaging Egypt: Options for US-Egypt Economic Relations, Peterson Institute for International Economics.

McNally, David (2011), «Night in Tunisia: Riots, Strikes and a Spreading Insurgency», The Bullet, No. 455, 19 January.

Mitchell, Timothy (1999), «Dreamland: The Neoliberalism of Your Desires», Middle East Research and Information Project (MERIP), No. 210, Spring.

World Bank (WB) (2010), Global Economic Prospects: Crisis, Finance and Growth, Washington. 